\title{
Characterization and Recovery of Apricot Germplasm from an Old Stone Collection
}

C. Martín and J.I. Hormaza

Estación Experimental "La Mayora"

CSIC, 29760 Algarrobo-Costa, Málaga

Spain

\author{
M. Herrero \\ Dep. Pomología, Estación Experimental \\ “Aula Dei”, CSIC, Apdo. 202/ 50080 \\ Zaragoza \\ Spain
}

Keywords: germplasm, maternal tissues, molecular markers, Prunus armeniaca

\begin{abstract}
The recovery and conservation of traditional fruit tree cultivars is a necessity that faces a short window of opportunity due to accelerating cultivar erosion. Several efforts to preserve old material took place before the widespread use of molecular markers, but often that material has not been conserved in ex situ germplasm collections. Here we present a case in Spain where a thorough inventory of local fruit tree species was performed in the $1950 \mathrm{~s}$ with detailed data of the origin of each genotype. However, from most of that material the only remnants are an old stone collection. We developed a protocol in apricot (Prunus armeniaca) to obtain DNA from maternal tissues of the stones of a sufficient quality to be amplified by PCR. Then we compared the results obtained with the profiles obtained from cultivars currently conserved in ex situ germplasm collections. The results highlight the lost and preserved variability and help to prioritize the recovery of particular cultivars. The approach used in this work provides information on genetic erosion that has taken place in fruit tree species, but could also be applied to other plant species.
\end{abstract}

\section{INTRODUCTION}

In the last decades the development of new technologies, the substitution of local varieties by foreign improved varieties or changes in cultural techniques, have resulted in an increasing erosion of germplasm resources that leads to the need of collecting endangered germplasm. In fact, conservation and use of plant genetic resources should be a priority in agricultural research (Tanksley and McCouch, 1997; Esquinas-Alcazar, 2005). However, this task is often hindered by the abundance of homonymies and synonymies in germplasm collections and the lack of information available on local germplasm erosion. In this work we present a case study with apricot (Prunus armeniaca L.) in Spain. A thorough variety inventory of different fruit tree species was performed in Spain in the 1950s with detailed data of the origin of each genotype (Herrero, 1964). However, from most of that material the only remnants are an old stone collection and most of the genotypes are no longer conserved in ex situ collections. Since two maternal tissues (the endocarp and the testa) are present in Prunus stones, it could be possible to extract DNA from them and predict the genetic composition of the maternal plant that originated the fruits. This could be a preliminary step to analyze genetic erosion during the last decades in different fruit tree species.

\section{MATERIALS AND METHODS}

A total of 45 apricot genotypes collected in the 1950s from different geographical areas in Spain and conserved in the form of stones at the E.E. Aula Dei in Zaragoza (Spain) were used in this study (Table 1). After trying different DNA extraction methods with both the testa and the endocarp (data not shown) we decided to use the protocol of Godoy and Jordano (2001) with some modifications. The maternal tissues were previously separated from the rest of the seed (endosperm and vestigial embryo) and treated with liquid nitrogen. DNA was extracted from 60 to $100 \mathrm{mg}$ of testa and endocarp. Tissues were homogenized in $400 \mu \mathrm{l}$ of extraction buffer $(200 \mathrm{mM}$ Tris- $\mathrm{HCl}$ 
pH 8.0; $70 \mathrm{mM}$ EDTA; $2 \mathrm{mM} \mathrm{NaCl} ; 20 \mathrm{mM}$ sodium bisulfite) with a TissueLyser homogenizer $(30 \mathrm{~s} ; 30 \mathrm{~Hz})$. After homogenization, $85 \mu 1$ of sarkosyl was added and the sample was incubated at $65^{\circ} \mathrm{C}$ for $30 \mathrm{~min}$ and centrifuged at $10,000 \mathrm{~g}$ for $20 \mathrm{~min}$ to remove insoluble material. In some cases this step had to be repeated for an additional 5 min. DNA was precipitated by the addition of $95 \mu 1$ of $10 \mathrm{M}$ ammonium acetate and 200 $\mu 1$ of isopropanol; the mixture was centrifuged for $20 \mathrm{~min}$ at $16,000 \mathrm{~g}$. The pellet was washed with $70 \%$ ethanol, dried and resuspended in $100 \mu \mathrm{MTE}$ buffer $(1 \mathrm{M}$ Tris-HCl pH 8.0; 0.5 M EDTA).

The extracted DNA was analyzed with 3 SSR loci developed in peach (Pcghms3, UDp96-001, UDp96-008) by Cipriani et al. (1999) and Sosinski et al. (2000) and proved to be transferable to apricot (Hormaza, 2002) and 9 loci developed in apricot (ssrPaCITA7, ssrPaCITA19, ssrPaCITA23, ssrPaCITA10, ssrPaCITA12, ssrPaCITA27, UDAp-414, UDAp-415, UDAp-420) by Lopes et al. (2002) and Messina et al. (2004) selected based on a higher number of alleles per locus and heterozigosity (Table 2).

A $15 \mu \mathrm{l}$ reaction containing $16 \mathrm{mM}\left(\mathrm{NH}_{4}\right)_{2} \mathrm{SO}_{4}, 67 \mathrm{mM}$ Tris-Cl pH 8.8, 0.01\% Tween20, $2 \mathrm{mM} \mathrm{MgCl}$, $0.1 \mathrm{mM}$ each dNTP, $0.4 \mu \mathrm{M}$ each primer, 40 ng genomic DNA and 1 unit of BioTaq DNA polymerase (Bioline, London, UK) were used for amplification on an I-cycler (Bio-Rad Laboratories, Hercules, CA, USA) thermocycler using the temperature profiles described in Table 2 for each primer set after optimizing the annealing temperatures with gradient PCR. Forward primers were labeled with a fluorescent dye on the 5' end (Proligo, Paris, France). The PCR products were analyzed by capillary electrophoresis in a CEQ ${ }^{\mathrm{TM}} 8000$ capillary DNA analysis system (Beckman Coulter, Fullerton, CA, USA). Samples were denatured at $90^{\circ} \mathrm{C}$ during $120 \mathrm{~s}$, injected at $2.0 \mathrm{kV} 30 \mathrm{~s}$ and separated at $6.0 \mathrm{kV}$ during $35 \mathrm{~min}$.

\section{RESULTS AND DISCUSSION}

As a preliminary work, DNA was extracted and amplified from both testa and endocarp tissues. The results obtained showed a higher quality and repeatability of the amplifications with testa tissue (data not shown) and, consequently, all the experiments were performed using that tissue. All the loci tested produced polymorphic amplification fragments among the apricot testa tissue studied. Six of the samples analyzed ('Duro', 'Currot', 'Patriarca Temprano', 'Nancy', 'Patriarca' and 'Mayeros') presented null alleles for 4 or more loci and for two samples ('Galta Rocha' and 'Corbató') it was not possible to obtain repeatable amplification patterns for most of the loci analyzed. Consequently, repeatable and reliable amplification patterns could be obtained for 37 old genotypes. The age of the samples and the fact that the fruit stones had been conserved at room temperature could explain the amplification problems detected with some samples.

A high number of 11 rare alleles $(p \leq 0.05)$ was obtained. However, only one allele was fixed ( $\mathrm{p} \geq 0.90)$, in the UDp96-008 locus. Some genotype-specific alleles were also observed. The combination of the different amplification fragments obtained with the 12 SSR loci allowed us to distinguish 37 unique genetic profiles revealing several cases of homonymies but no synonymies were found in the material studied.

When the results obtained were compared with an ex situ apricot germplasm collection (Hormaza, 2002) only three of the genotypes analyzed in this work ('Luizet', 'Canino' and 'Gitano') have the same genotype profile suggesting that the rest of the genotypes are no longer conserved in the ex situ collection analyzed. These results support the use of the approach described in this work. In fact, two different 'Canino' accessions were conserved as stones and one of them proved to be the same as the genotype conserved ex situ. On the other hand, a homonymy was found between the genotype Paviot conserved in form of stones and the cultivar with the same name conserved ex situ, since the amplification profiles were different.

The results obtained in this work will be highly useful to help us to prioritize which apricot varieties should be collected in the future. The approach used can also be of great interest to study the loss of genetic diversity and the genetic erosion that has taken place in apricot and it could be applied to other plant species, provided that old 
material is still preserved.

\section{ACKNOWLEDGEMENTS}

Financial support for this work was provided by the Spanish Ministry of Education (Project Grants AGL2004-02290/AGR, AGL2006-13529 and AGL200760130/AGR), GIC-Aragón 43. C.M. was supported by a grant from the Mediterranean Agronomic Institute of Zaragoza (IAMZ). The authors would like to thank J. Rodrigo and the CITA of Aragon for providing leaf material for genetic analyses.

\section{Literature Cited}

Cipriani, G., Lot, G., Huang, W.G., Marrazzo, M.T., Peterlunger, E. and Testolin, R. 1999. AC/GT and AG/CT microsatellite repeats in peach [Prunus persica (L) Batsch]: isolation, characterisation and cross-species amplification in Prunus. Theor. Appl. Genet. 99:65-72.

Esquinas-Alcazar, J. 2005. Protecting crop genetic diversity for food security: political, ethical and technical challenges. Nature Rev. Genet. 6:946-953.

Godoy, J.A. and Jordano, P. 2001. Seed dispersal by animals: exact identification of source trees with endocarp DNA microsatellites. Mol. Ecol. Notes 10:2275-2283.

Herrero, J. 1964. Cartografia de las variedades de frutales de hueso y pepita. CSIC Aula Dei, Zaragoza, Spain.

Hormaza, J.I. 2002. Molecular characterization and similarity relationships among apricot (Prunus armeniaca L.) genotypes using simple sequence repeats. Theor. Appl. Genet. 104:321-328.

Lopes, M.S., Sefc, K.M., Laimer, M. and Da Câmara Machado, A. 2002. Identification of microsatellite loci in apricot. Mol. Ecol. Notes 2:24-26.

Messina, R., Lain, O., Marrazzo, M.T., Cipriani, G. and Testolin, R. 2004. New set of microsatellite loci isolated in apricot. Mol. Ecol. Notes 4:432-434.

Sosinski, B., Gannavarapu, M., Hager, L.D., Beck, L.E., King, G.J., Ryder, C.D., Rajapakse, S., Baird, W.V., Ballard, R.E. and Abbott, A.G. 2000. Characterization of microsatellite markers in peach [Prunus persica (L.) Batsch]. Theor. Appl. Genet. 101:421-42.

Tanksley, S.D. and McCouch, S.R. 1997. Seed banks and molecular maps: Unlocking genetic potential from the wild. Science 277:1063-1066. 


\section{$\underline{\text { Tables }}$}

Table 1. List of the cultivars studied that are conserved in form of stones.

\begin{tabular}{ll}
\hline & Cultivars \\
\hline Acmé & Luizet \\
Amoscatelado & Mayeros \\
Antón & Moniquí \\
Blanco de Murcia 1 & Moniquí Temprano \\
Blanco de Murcia 2 & Nancy \\
Canino 1 & Patriarca \\
Canino 2 & Patriarca de Hueso Dulce \\
Carmelos & Patriarca Temprano \\
Corbató & Paviot \\
Currot & Perla \\
Damasco & Precoz de Boulbon \\
De Antón & Real Fino 1 \\
De Confitar & Real Fino 2 \\
De Hellín & Real Temprano 1 \\
Duro & Real Temprano 2 \\
Encarnado Fino & San Ambrosio \\
Galta Rocha & Santones \\
Galta Vermeya & Tapalahoja \\
Giletano 1 & Temprano Colomer \\
Giletano 2 & Temprano Gordo \\
Gitano & Toledo \\
Hatif Colomer & Velázquez \\
Hoja de Parra & \\
\hline
\end{tabular}

Table 2. Primers and PCR conditions used in this work.

\begin{tabular}{|c|c|c|c|c|}
\hline Primers & Denaturation & Annealing & Elongation & N Cycles \\
\hline Pcghms3 & $94^{\circ} \mathrm{C} 45 \mathrm{~s}$ & $57^{\circ} \mathrm{C} 30 \mathrm{~s}$ & $72^{\circ} \mathrm{C} 30 \mathrm{~s}$ & 32 \\
\hline UDp96-001 & $94^{\circ} \mathrm{C} 45 \mathrm{~s}$ & $57^{\circ} \mathrm{C} 45 \mathrm{~s}$ & $72^{\circ} \mathrm{C} 45 \mathrm{~s}$ & 35 \\
\hline UDp96-008 & $94^{\circ} \mathrm{C} 45 \mathrm{~s}$ & $57^{\circ} \mathrm{C} 45 \mathrm{~s}$ & $72^{\circ} \mathrm{C} 45 \mathrm{~s}$ & 35 \\
\hline ssrPaCITA7 & $96^{\circ} \mathrm{C} 30 \mathrm{~s}$ & $51^{\circ} \mathrm{C} 45 \mathrm{~s}$ & $72^{\circ} \mathrm{C} 30 \mathrm{~s}$ & 34 \\
\hline ssrPaCITA19 & $96^{\circ} \mathrm{C} 30 \mathrm{~s}$ & $51^{\circ} \mathrm{C} 45 \mathrm{~s}$ & $72^{\circ} \mathrm{C} 30 \mathrm{~s}$ & 34 \\
\hline ssrPaCITA23 & $96^{\circ} \mathrm{C} 30 \mathrm{~s}$ & $51^{\circ} \mathrm{C} 45 \mathrm{~s}$ & $72^{\circ} \mathrm{C} 30 \mathrm{~s}$ & 34 \\
\hline ssrPaCITA10 & $96^{\circ} \mathrm{C} 30 \mathrm{~s}$ & $47^{\circ} \mathrm{C} 45 \mathrm{~s}$ & $72^{\circ} \mathrm{C} 30 \mathrm{~s}$ & 34 \\
\hline ssrPaCITA12 & $96^{\circ} \mathrm{C} 30 \mathrm{~s}$ & $47^{\circ} \mathrm{C} 45 \mathrm{~s}$ & $72^{\circ} \mathrm{C} 30 \mathrm{~s}$ & 34 \\
\hline ssrPaCITA27 & $96^{\circ} \mathrm{C} 30 \mathrm{~s}$ & $47^{\circ} \mathrm{C} 45 \mathrm{~s}$ & $72^{\circ} \mathrm{C} 30 \mathrm{~s}$ & 34 \\
\hline UDAp-414 & $94^{\circ} \mathrm{C} 30 \mathrm{~s}$ & $56^{\circ} \mathrm{C} 45 \mathrm{~s}$ & $72^{\circ} \mathrm{C} 30 \mathrm{~s}$ & 27 \\
\hline UDAp-415 & $94^{\circ} \mathrm{C} 30 \mathrm{~s}$ & $56^{\circ} \mathrm{C} 45 \mathrm{~s}$ & $72^{\circ} \mathrm{C} 30 \mathrm{~s}$ & 27 \\
\hline UDAp-420 & $94^{\circ} \mathrm{C} 30 \mathrm{~s}$ & $56^{\circ} \mathrm{C} 45 \mathrm{~s}$ & $72^{\circ} \mathrm{C} 30 \mathrm{~s}$ & 27 \\
\hline
\end{tabular}

